\title{
Comparative Analysis of Salinity Responsive Candidate Gene Expression in Selected Sri Lankan Rice Varieties
}

\author{
D.R. Gimhani ${ }^{*}$, G. Vergara ${ }^{2}$, G.B. Gregorio ${ }^{2}$ and N.S. Kottearachchi ${ }^{1}$
}

\begin{abstract}
Studying of expression dynamics of salt responsive candidate genes under different genetic background of rice is important to develop resilient salt tolerant rice varieties. The present study was focused to assess the comparative expression of salinity responsive genes which are involved in $\mathrm{Na}^{+} / \mathrm{K}^{+}$homeostasis (OsNHX1), signal transduction pathway (OSMAPK5, OsCDPK7) and synthesis of osmoprotectant (OSTPS1). Comparative expression of selected genes were assessed in At354 (improved), Godawee (traditional) and Kuruwi Perunel (traditional), salinity tolerant varieties and Suwandel, a salinity susceptible traditional variety. The assessment was done before salinization (at 0 h) and after salinization at $24 \mathrm{~h}$ and $72 \mathrm{~h}$ using semi-quantitative Reverse Transcriptase PCR (RT-PCR). RT-PCR products were analysed using $1.5 \%$ agarose gel electrophoresis. Resulted gel profiles were assessed and relative level of gene expression was measured based on the intensity of the PCR product in terms of average pixel values. Relative level of gene expression in four varieties was plotted against the exposure time to salinity. Accordingly, marked variation in expression pattern of the selected genes was detected in four varieties over the tested in Godawee and Suwandel compared to At354 and Kuruwi Perunel. At $24 \mathrm{~h}$, all four genes were up-
\end{abstract}

\footnotetext{
${ }^{1}$ Department of Biotechnology, Faculty of Agriculture and Plantation Management, Wayamba University of Sri Lanka, Makandura, Gonawila, NWP, Sri Lanka.

${ }^{2}$ International Rice Research Institute, DAPO Box 7777, Metro Manila, Philippines.

*drgimhani@yahoo.com
}

regulated in At354 and Godawee while they were down-regulated in Suwandel. In Kuruwi Perunel, OsNHX1, OsMAPK5 and OsCDPK7 genes were up-regulated at $24 \mathrm{~h}$ while OsTPS1 was up-regulated at $72 \mathrm{~h}$. At $72 \mathrm{~h}$, continuous expression of all genes was observed in Kuruwi Perunel and Godawee, whereas expression was comparatively down-regulated in At354 approximately to the same level under non-stress condition. It could be suggested that At354 might have been adapted to the stress relatively earlier compared to Godawee and Kuruwi Perunel, where expressions of genes were less pronounced. Further experiments with various time period of salinity exposure should be carried out to make detailed inference regarding the expression dynamics in tested rice varieties.

Keywords: Gene expression, Rice, RTPCR, Salinity tolerance

\section{INTRODUCTION}

Soil salinity is considered as the second most widespread soil problem causing the significant reduction in productivity of global rice cultivation (Gregorio et al., 1997; Ashraf and O'Leary, 1996; Munns et al., 2006). Degree of salinity tolerance in rice varies with the stage of development. Rice is relatively tolerant to salinity during germination, active tillering, and maturity period whereas it is highly sensitive to salinity during early seedling and reproduction stages (Lafitte et al., 2004; Pearson and Bernstein, 1959). Growthstage-dependent salinity tolerance in rice is 
mainly associated with salt exclusion or low uptake, compartmentalization of toxic ions in structural and older tissues, higher tissue tolerance, responsive stomata that close faster upon exposure to salt stress, upregulation of antioxidant systems for protection against reactive oxygen species generated during stress and vigorous growth to dilute salt concentration in plant tissue (Yeo and Flowers, 1986; Yeo et al., 1990; Peng and Ismail, 2004; Moradi and Ismail, 2007). Accordingly, salinity tolerance in rice is a complex mixture of mopho-physiological traits, which is controlled by multiple genes (Chinnusamy et al., 2005). Ismail et al. (2007) has reported that in rice most salt-tolerant genotypes are superior in only one or a few of these traits and therefore there is a potentiality to pyramid superior alleles for all useful mechanisms into one rice genotype towards producing resilient salt tolerant varieties (Ismail et al., 2007). Therefore, it is essential to understand the fundamental molecular mechanisms behind stress tolerance in plants. Considerable progress towards understanding the molecular basis of salt tolerance in rice has been made during the last two decades and number of genes involved in signal transduction, transcription regulation, ion transporters and metabolic pathways, conferring salt tolerance in rice have been isolated (Ismail et al., 2007; Kumar et al., 2013).

Response to salinity stress in rice begins with the acquisition and transmission of the stress signals through signalling components, which would activate the stress-related genes leading to synthesis of diverse functional proteins responsible for various physiological and metabolic responses (Kumar et al., 2013; Basu and Roychoudhury, 2014). The comprehensive understanding of the biological functions of these candidate genes is one of the greatest challenges in functional genomics research, which has to be revealed through the determination of their expression profiles (Basu and Roychoudhury, 2014). Transcriptomic analysis provides detailed knowledge about the gene expression at mRNA level, which is widely used to screen candidate genes involved in stress responses. Genomic approaches play a significant role in encoding, cloning, and characterization of important genes. The vast number of saltresponsive candidate genes which are either up-regulated or down-regulated in response to salinity stress have been identified and characterized using transcriptomic and genomic approaches such as microarrays, RNAseq, quantitative real time PCR (qRTPCR) and semi-quantitative RT-PCR expression analysis methods (Ismail et al., 2007; Negrao et al., 2011; Gupta and Huang, 2014). These include signalling genes (Boonburapong and Buaboocha, 2007; Chen et al., 2006; Martinez-Atienza et al., 2007; Wan et al., 2007), genes involved in ion homeostasis (Garciadeblas et al., 2003; Horie et al., 2007; Fukuda et al., 2010) and in the synthesis of osmoprotective proteins (Wang et al., 2007), as well as transcription factors (Liu et al., 2007; Matsukura et al., 2010) and genes involved in the rapid posttranslational regulation of cell proteomes 
(Martinez-Atienza et al., 2007; Khan et al., 2005).

Thus, present study was mainly focused on four selected salt responsive candidate genes and to study their expression in relation to up or down regulation in selected Sri Lankan rice varieties under salt stress condition, aiming at using them in future breeding purpose.

\section{MATERIALS AND METHODS Plant Material and Stress Treatment}

The study was conducted at the laboratory of International Rice Research Institute (IRRI), Philippines. Two traditional salt tolerant local rice varieties, i.e. Kuruwi Perunel (IRGC Ac No: 8994) and Godawee (IRGC Ac No 15653), one traditional salt susceptible local variety, Suwandel (IRGC Ac No 31552) obtained from IRRI and salt tolerant improved variety, At354 collected from Rice Research and Development Institute (RRDI), Batalagoda, Sri Lanka were used for the present study based on the assessment of salt tolerance in our previous studies.

Surface sterilized seeds thoroughly rinsed with distilled water were placed on moistened filter papers in Petri dishes and incubated at $30^{\circ} \mathrm{C}$ for $48 \mathrm{~h}$. Pre-germinated seeds were sown in holes on Styrofoam floats with a nylon net bottom suspended on trays filled with water. After 2 days, when seedlings were well established, water was replaced with Peter's nutrient solution (Perter's 1 g/L) (Scotts Peters (20-20-20) Professional water-soluble fertilizer) supplemented with $\mathrm{FeSO}_{4} .7 \mathrm{H}_{2} \mathrm{O} \quad(300$ $\mathrm{mg} / \mathrm{L})$ ). Seedlings were grown inside the growth chamber under the controlled conditions of $12 \mathrm{~h}$ light with $29{ }^{\circ} \mathrm{C}$ temperature and $12 \mathrm{~h}$ dark with $21{ }^{\circ} \mathrm{C}$ temperature, $80 \%$ Relative humidity $(\mathrm{RH})$ and the photoperiod of $200 \mu \mathrm{mol}$ photons $\mathrm{m}^{-2} \mathrm{~s}^{-1}$ photo intensity at the IRRI. The $\mathrm{pH}$ of the nutrient solution was adjusted to 5.0 every other day by adding $1 \mathrm{M} \mathrm{NaOH}$ or 1 $\mathrm{M} \mathrm{HCl}$. After 4 days, nutrient solution was salinized upto $100 \mathrm{mM}$ (EC $12 \mathrm{dS} / \mathrm{m}$ ) by adding appropriate amount of analytical grade $\mathrm{NaCl}$.

\section{Sampling of Tissues}

Shoot and root samples of each variety were harvested just before the salinization to serve as a control, $24 \mathrm{~h}$ after salinization and 72 h (3 days) after salinization. Predetermined weight of shoot and root samples were harvested quickly into the eppendorf tubes with a hole and immersed in liquid nitrogen within less than 1 minute to minimize the expression of new mRNAs because of tissue wounding or detachment from the plant. After harvesting all the samples were stored in the $-80{ }^{\circ} \mathrm{C}$ freezer until use for the RNA extractions.

\section{Extraction of Total Plant RNA}

Total RNA was isolated from frozen shoot and root samples together using TRIzol Reagent (Invitrogen, Carlsbad, USA) according to the manufactures instructions and Sambrook et al. (1989). RNA samples were treated with RNase free DNase 1 (Promega, USA) to remove genomic DNA 
contaminations in the extracted RNA samples according to manufactures instructions. Quality and quantity of the RNA preparations were assessed using both $2 \%$ non-denaturing agarose gel electrophoresis and by NanoDrop 8000 UV spectrophotometer (Thermo Scientific, USA) with respect to the absorbance at 260 $\mathrm{nm}, 280 \mathrm{~nm}$ and $230 \mathrm{~nm}$.

\section{Designing of Candidate Gene Specific Primers for Semi-Quantitative Reverse Transcriptase - PCR (RT-PCR)}

In present study, four candidate genes were selected based on the previous studies regarding salinity responsive candidate genes. Triosephosphate isomerise (TPI) housekeeping gene was taken as the reference gene for normalization of transcripts (Table 1). Candidate gene specific primers for RT- PCR was designed using Roche Universal Probe Library Assay design center with ProbeFinder software version 2.49 for rice, which is based on Primer3 software. The Coding sequences of the selected candidate genes were retrieved from the sequence databases of National Center for Biotechnology Information (NCBI) (www.ncbi.nlm.nih.gov) and Rice genome annotation project (http:// rapdb.dna.affrc.go.jp/) and fed to Roche Universal Probe Library Assay design center as input sequences. Primers were designed according to the method of intronspanning assay in order to eliminate the false positive signals from residual genomic DNA, with the default optimized settings of the software. Details of the designed RTPCR primers for four candidate genes and TPI housekeeping gene are mentioned in the Table 2.

Table 1. Selected salt responsive candidate genes

\begin{tabular}{|c|c|c|c|c|}
\hline $\begin{array}{l}\text { Candidate } \\
\text { gene }\end{array}$ & Locus ID & $\mathrm{Ch}^{\mathrm{a}}$. & Description of gene & References \\
\hline \multirow[t]{2}{*}{ OsNHX1 } & Os07g0666900 & 7 & $\begin{array}{l}\text { Intracellular NHX proteins are } \mathrm{Na}+\text {, } \\
\mathrm{K}+/ \mathrm{H}+\text { antiporters involved in } \mathrm{K}+ \\
\text { homeostasis } \\
\text { compartmentalization of } \mathrm{Na}+\text { and } \\
\mathrm{K}+\text { ) }\end{array}$ & $\begin{array}{l}\text { Ahmadi et al.,2011; } \\
\text { Gupta and Huang, 2014; } \\
\text { Kumar et al., 2013; } \\
\text { Ismail et al., 2007; Chen } \\
\text { et al., 2007; Fukuda et al., } \\
2010\end{array}$ \\
\hline & & & $\begin{array}{l}\text { NHX1- NHX isoform localized in } \\
\text { tonoplast is essential for } \\
\text { compartmentalization of } \mathrm{Na}+\text { into } \\
\text { the vacuoles under salinity stress }\end{array}$ & \\
\hline OSTPS1 & Os05g0518600 & 5 & Trehalose-6-phospate synthase & $\begin{array}{l}\text { Kumar et al., 2013; Li et } \\
\text { al., } 2011\end{array}$ \\
\hline OsMAPK5 & Os03g0285800 & 3 & $\begin{array}{l}\text { Mitogen-activated protein kinase } \\
\text { (MAPK) }\end{array}$ & $\begin{array}{l}\text { Kumar et al., 2013, } \\
\text { Xiong and Yang, } 2003\end{array}$ \\
\hline
\end{tabular}




\begin{tabular}{lllll} 
OsCDPK7 & Os04g0584600 & 4 & $\mathrm{Ca}^{2+}$ dependent protein kinases & $\begin{array}{l}\text { Kumar } \text { et al., 2013, Saijo } \\
\text { et al., } 2000\end{array}$ \\
OsTPI & Os01g0147900 & 1 & $\begin{array}{l}\text { Triosephosphate isomerise } \\
\text { (housekeeping gene) }\end{array}$ & Maksup et al., 2013 \\
\hline
\end{tabular}

${ }^{a}$ Chromosome

\section{Semi-Quantitative Reverse Transcriptase- Polymerase Chain Reaction (RT-PCR)}

First-strand cDNA was synthesized from 4 $\mu \mathrm{g}$ of total RNA using the SuperScript ${ }^{\mathrm{TM}}$ First-Strand Synthesis System for RT-PCR (Invitrogen, Carlsbad, USA) according to manufacturer's protocol. All the cDNA samples prepared from the At354, Godawee, Kuruwi Perunel and Suwandel harvested in $0 \mathrm{~h}$ (just before salinization), $24 \mathrm{~h}$ and $72 \mathrm{~h}$ after salinization were diluted to equal concentrations of $200 \mathrm{ng} / \mu \mathrm{l}$ and amplified using selected 4 salt responsive candidate gene specific primers along with the OsTPI housekeeping gene (Table 2). The PCR mixture $(20 \mu \mathrm{l})$ consisted of $1 \mu \mathrm{l}$ of cDNA (200 ng/ $\mu \mathrm{l}), 2 \mu \mathrm{l}$ of $10 \mathrm{X} \mathrm{MgCl}_{2}$ free PCR buffer, $1.2 \mu 1$ of $\mathrm{MgCl}_{2}(25 \mathrm{mM})$, $0.4 \mu \mathrm{l}$ of dNTPs $(2.5 \mathrm{mM}$ of each dNTP), $0.4 \mu \mathrm{l}$ of forward primer $(10 \mu \mathrm{M}), 0.4 \mu \mathrm{l}$ of Reverse primer $(10 \mu \mathrm{M})$ (Invitrogen, USA) and $0.16 \mu \mathrm{l}$ of Taq DNA polymerase (5 $\mathrm{U} / \mu \mathrm{l})$ (iNtRON Biotechnology, Inc.). Final volume of the mixture was adjusted to $20 \mu \mathrm{l}$ by adding sterile nano pure water. PCR amplification was performed using GStorm Thermal Cycler (Model GS1, Gene Technologies, Essex, UK) and amplification profile consisted of initial denaturing at $94{ }^{\circ} \mathrm{C}$ for 2 minutes followed by 35 cycles of 15 seconds at $94{ }^{\circ} \mathrm{C}, 45$ seconds at $55^{\circ} \mathrm{C}$ seconds at $55^{\circ} \mathrm{C}, 1$ minute at $72{ }^{\circ} \mathrm{C}$ and final extraction cycle of 8 minutes at $72{ }^{\circ} \mathrm{C}$.

Semi-quantitative RT-PCR experiment was conducted in duplicate for each primer in order to confirm the reproducibility of the specific expression profiles in each variety at different time intervals under salinity stress.

\section{Assessment of Differential Expression of Candidate Genes}

The PCR products $(20 \mu \mathrm{l})$ were mixed with $2 \mu \mathrm{l}$ of $6 \mathrm{X}$ loading buffer and separated on $1.5 \%$ agarose gel. After SYBR-Safe (Invitrogen, Carlsbad, USA) staining ( $5 \mu 1$ of SYBR-Safe per $50 \mathrm{ml}$ of nanopure water), gel was visualized under UV light using Alpha Innotech gel documentation system. Photographic images were obtained using the gel documentation system and differential level of expression in candidate genes was assessed based on the relative intensity of fragments. Intensity of fragments was measured using ImageJ [version 1.49] (Schneider et al., 2012) software in terms of average pixel values. Estimated level of expression of each gene in terms of average pixel values in 4 varieties was plotted against the exposure 
time to salinity, in order to make inferences regarding the differential expression of genes over the tested time period under salinity stress.

\section{RESULTS}

In present study, all of these gene specific RT-PCR primers designed according to intron- spanning assay were able to produce positive amplification with the expected size of product indicating the specificity and efficacy of all the designed RT- PCR primers (Table 2; Figure 1). In addition, present results revealed the differential level of expression with respect to four selected salt responsive candidate genes, in 4 varieties under salinity stress and nonsaline conditions (Figure 1 and Figure 2).

\section{Expression of OsTPI Housekeeping Gene}

According to the semi-quantitative RTPCR analysis, all 4 varieties viz., At354, Kuruwi Perunel, Godawee and Suwandel exhibited equal level of expression under salinity stress and non-saline conditions with respect to the OSTPI housekeeping gene exhibiting constitutive expression of OSTPI housekeeping gene irrespective of the different genetic background, developmental and environmental conditions (Figure 1).

\section{Expression of OsNHX1 Gene}

With respect to the expression of OsNHXI gene, At354 and Kuruwi Perunel exhibited relatively low level of gene expression under non-stress condition compared to
Godawee and Suwandel (Figure 1 and Figure 2). After $24 \mathrm{~h}$ of salinity stress, $O s N H X 1$ gene expression was relatively upregulated in At354 and Kuruwi Perunel (Figure 1 and Figure 2). At this time compared to Kuruwi Perunel, At354 exhibited relatively higher number transcript abundance. And also, $24 \mathrm{~h}$ after salinity stress, OsNHX1 gene expression in Godawee was slightly up-regulated compared to non-stress condition, whereas in Suwandel gene expression was drastically down-regulated (Figure 1 and Figure 2). With the extension of salinity stress for $72 \mathrm{~h}$, it was noted that in At354, gene expression was again declined to the level comparable to the non-stress condition. In contrast, Kuruwi Perunel exhibited comparatively higher abundance of transcripts at $72 \mathrm{~h}$ after salinity stress condition (Figure 1 and Figure 2). At this time, Godawee again showed the same amount of transcripts of $O s N H X 1$ gene comparable to non-stress condition while OsNHX1 gene expression was not observed in Suwandel (Figure 1 and Figure 2).

\section{Expression of OsCDPK7 gene}

Relatively low level of expression of the OsCDPK7 gene was also observed in At354 and Kuruwi Perunel under non-saline conditions whereas Godawee and Suwandel exhibited relatively higher level of gene expression under non-saline condition (Figure 1 and Figure 2). After $24 \mathrm{~h}$ of salinity treatment, it was noted the upregulation of gene expression in At354, Kuruwi Perunel and Godawee (Figure 1 and Figure 2). Of them highest amount of 
transcript abundance was observed in Godawee. However, expression of OsCDPK7 was drastically down regulated compared to non-saline condition in Suwandel (Figure 1 and Figure 2). With the extension of salinity stress until $72 \mathrm{~h}$, expression of OsCDPK7 was comparatively declined both in At354 and Godawee. However, compared to At354, Godawee exhibited relatively higher transcript abundance (Figure 1 and Figure 2). In contrast to that, Suwandel exhibited relatively higher up-regulation of gene expression while level of gene expression was slightly up-regulated in Kuruwi Perunel compared to $24 \mathrm{~h}$ after salinity stress (Figure 1 and Figure 2).

\section{Expression of OsMAPK5 gene}

According to the expression of OSMAPK5 gene, relatively higher abundance of transcripts of $O S M A P K 5$ was detected in Godawee and Suwandel compared to At354 and Kuruwi Perunel under non-saline conditions (Figure 1 and Figure 2). Expression of gene was up-regulated after $24 \mathrm{~h}$ of salinity stress in At354, Kuruwi Perunel and Godawee. Of them, highest level of transcripts of OSMAPK5 gene was detected in Godawee (Figure 1 and Figure 2). However, expression of OsMAPK5 gene was drastically down-regulated in Suwandel compared non-saline condition (Figure 1 and Figure 2). After 72 h of sanity stress, level of gene expression was downregulated to the level comparable to nonsaline condition in At354 (Figure 1 and Figure 2). However, Kuruwi Perunel exhibited progressively up-regulation of expression in OsMAPK5 gene with the extension of salinity stress period (Figure 1 and Figure 2). In contrast to that, transcript abundance of OSMAPK5 gene was slightly lowered in Godawee after 72 h of salinity treatment compared to $24 \mathrm{~h}$ after salinity treatment. In addition, expression of OSMAPK5 gene was progressively downregulated in Suwandel with the extension of time period under saline condition (Figure 1 and Figure 2).

\section{Expression of OsTPS1 gene}

Under non-saline condition, OSTPS1 gene expression was not observed in At354 and Kuruwi Perunel whereas gene expression was detected in Godawee and Suwandel (Figure 1 and Figure 2). Compared to Suwandel, Godawee exhibited relatively high amount of transcripts of OsTPS1 gene (Figure 1 and Figure 2). After $24 \mathrm{~h}$ of salinity stress, up-regulation of OSTPS1 gene expression was detected in both At354 and Godawee whereas expression was not detected in Suwandel and Kuruwi Perunel (Figure 1 and Figure 2). However, level of of gene expression was relatively high in Godawee compared to the expression in At354. It was noted that after $72 \mathrm{~h}$ of salinity stress condition, again OsTPS1 gene was not expressed in At354 while expression of OsTPS1 gene was observed in Kuruwi Perunel and Suwandel (Figure 1 and Figure 2). However, compared to Kuruwi Perunel, Suwandel exhibited relatively low amount of transcripts of OsTPS1 gene. At this time, level of gene expression in Godawee was slightly lowered compared to the gene expression level at $24 \mathrm{~h}$ after salinity stress (Figure 1 and Figure 2). 
Table 2. Details of designed candidate gene specific RT-PCR primers

\begin{tabular}{|c|c|c|c|c|c|c|c|}
\hline Gene & Primer F 5'-3' (Left) & Primer R 5'3’' (Right) & $\begin{array}{l}\mathrm{T}_{\mathrm{m}} \\
{ }^{\circ} \mathrm{C}\end{array}$ & $\begin{array}{l}\text { Size of } \\
\text { amplicon } \\
\text { (nt) }\end{array}$ & $\begin{array}{l}\text { spanned } \\
\text { intron } \\
\text { size } \\
(\mathrm{nt})\end{array}$ & $\begin{array}{c}\text { Total if } \\
\text { genomic } \\
\text { DNA (nt) }\end{array}$ & Reference Gene sequence \\
\hline OsNHX1 & $\begin{array}{l}\text { CTGTCGTTCTTTTTAGCA } \\
\text { CTATGG }\end{array}$ & $\begin{array}{l}\text { GGTGACAGGATGGCCT } \\
\text { GA }\end{array}$ & 55 & 89 & 571 & 660 & $\begin{array}{c}\text { O.sativa Japonica Group } \\
\text { OsNHX1 mRNA, (complete } \\
\text { cds.) }\end{array}$ \\
\hline OsTPS1 & $\begin{array}{l}\text { GTTTCAAGCGAGCATTGG } \\
\text { AG }\end{array}$ & $\begin{array}{l}\text { TCGGTCAACACCAAGC } \\
\text { ATTA }\end{array}$ & 55 & 98 & 659 & 757 & $\begin{array}{l}\text { O.sativa Indica Group } \\
\text { trehalose-6-phosphate synthase } \\
1 \text { (TPS1) mRNA, complete cds } \\
\text { (gi|328864180|gb|HM050424.1 } \\
\text { )| }\end{array}$ \\
\hline OsMAPK5 & $\begin{array}{l}\text { CCGCTGCAGAGAATCAC } \\
\text { AG }\end{array}$ & $\begin{array}{l}\text { TGCTCGAAGTCGAAGG } \\
\text { AGA }\end{array}$ & 55 & 113 & 524 & 637 & $\begin{array}{c}\text { O. sativa MAP kinase } \\
\text { MAPK5a (MAPK5) mRNA, } \\
\text { complete cds, alternatively } \\
\text { spliced.(AF479883.1|AF47988 } \\
\text { 3:EMBL) }\end{array}$ \\
\hline OsCDPK7 & $\begin{array}{l}\text { TCTCGCTCAAGGCCATAG } \\
\text { AT }\end{array}$ & $\begin{array}{l}\text { CAACAACACTTCTGGA } \\
\text { GCTACG }\end{array}$ & 55 & 107 & 523 & 630 & $\begin{array}{c}\text { O. sativa Japonica Group } \\
\text { mRNA for OsCDPK7, } \\
\text { complete } \\
\text { cds.(AB042550.1|AB042550:E } \\
\text { MBL) }\end{array}$ \\
\hline OsTPI & $\begin{array}{l}\text { TGC TGC ACA AAC AAA } \\
\text { AGC A }\end{array}$ & $\begin{array}{l}\text { CTT CTT GTG CTT GAT } \\
\text { CTG GTG T }\end{array}$ & 55 & 122 & 480 & 602 & $\begin{array}{l}\text { O. sativa Japonica Group } \\
\text { Os01g0147900 } \\
\text { (Os01g0147900) mRNA, } \\
\text { complete cds } \\
\text { (ref|NM_001048551.1|) }\end{array}$ \\
\hline
\end{tabular}




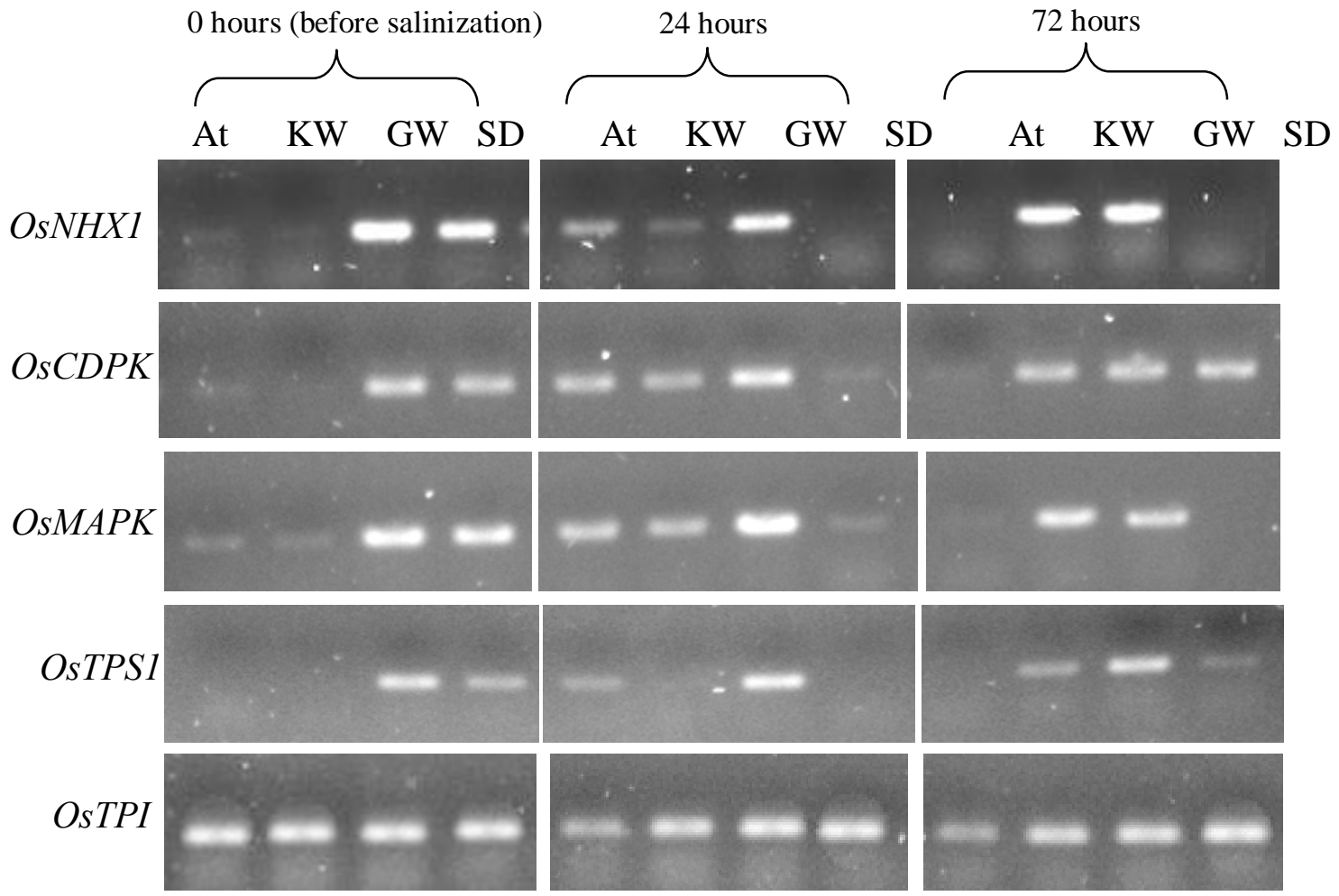

Figure 1. $1.5 \%$ agarose gel electrophoresis of amplified cDNA from At354 (At), Kuruwi perunel (KW), Godawee (GW) and Suwandel (SD) in $0 \mathrm{~h}$ (before salinization), $24 \mathrm{~h}$ after salinization and $72 \mathrm{~h}$ after salinization with OsNHX1, OsCDPK7, OsMAPK5, OsTPS1 and OsTPI (housekeeping gene) gene specific primers.

\section{DISCUSSION}

Even though rice is considered to be generally salt sensitive, there is a wide spectrum of genetic variation for the salt tolerant mechanisms at critical stages i.e. early seedling and reproductive stages, in the rice gene pool (Yeo and Flowers, 1986; Moradi et al., 2003). Therefore, identification and functional characterization of salt responsive candidate genes would be important to understand the salinity tolerant mechanisms for the genetic improvement of rice tolerance to salinity (Wu et al., 2005).
There are two major phases of salinity stress as osmotic stress and ionic stress. Plants usually achieve osmotic homeostasis during several hours or at least within the first day following salt stress (Munns, 2002). The ionic stress component of salinity stress, as a second phase, becomes gradually more severe, typically beginning after 1-3 days of salinity stress $(\mathrm{NaCl}$ application) despite rapid influx of $\mathrm{Na}^{+}$ions and transport to the shoots. This is because the concentration of $\mathrm{Na}^{+}$must reach a certain toxic level in cell protoplasts of shoots and this process requires some days (Munns, 2002; Munns, 2005; Roshandel 
D.R. Gimhani, G. Vergara, G.B. Gregorio and N.S. Kottearachchi

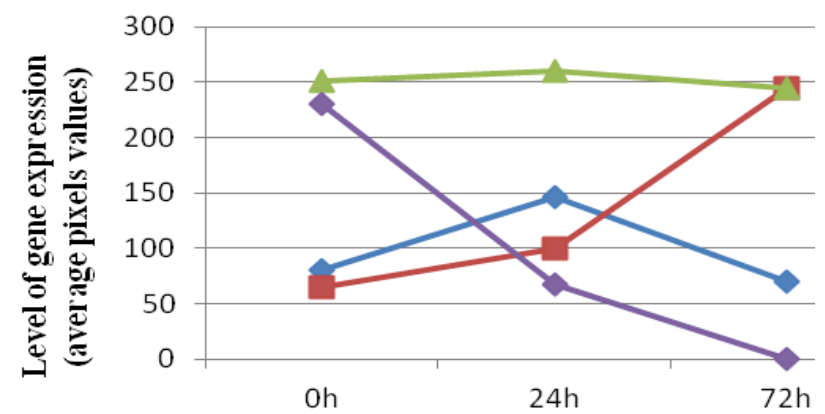

Exposure time to salinity (hours) OsNHX1

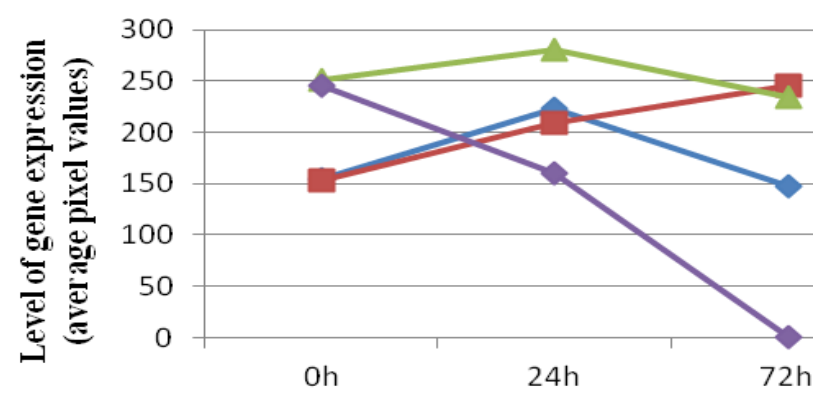

Exposure time to salinity (hours) OSMAPK5

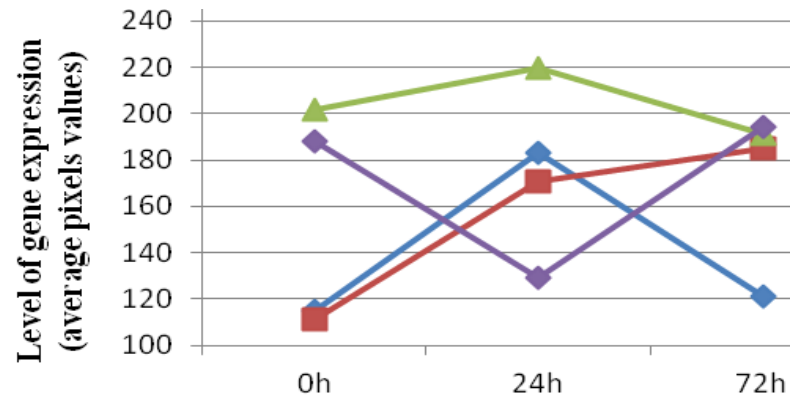

Exposure time to salinity (hours) $O S C D P K$

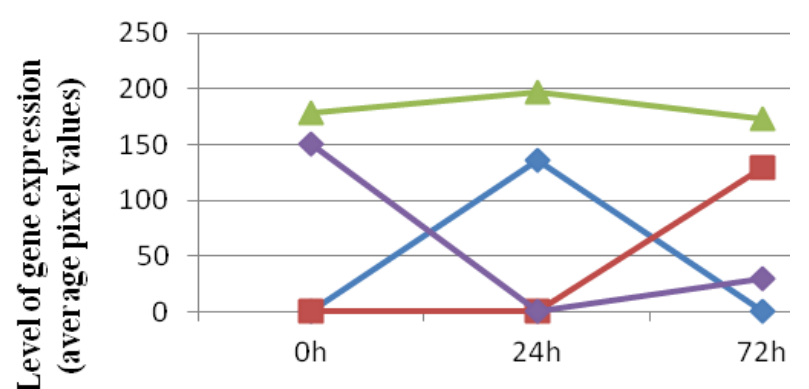

Exposure time to salinity (hours) OsTPS1

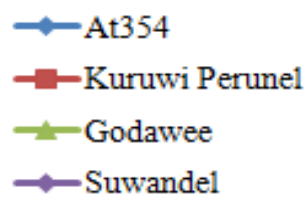

Figure 2. Differential expression of $O s N H X 1, O s C D P K 7, O s M A P K 5$ and OsTPS1 candidate genes in At354, Kuruwi Perunel, Godawee and Suwande

and Flowers, 2009). After 24-72 h of salinity stress, the concentration of $\mathrm{Na}+$ in cytoplasm may be close to toxic level and, therefore, plants react to the ionic stress progressively. $\mathrm{Na}^{+}$exclusion, $\mathrm{Na}^{+}$ compartmentalization and $\mathrm{Na}^{+}$reabsorption are common mechanisms of tolerance to the ionic component of salt stress, where one or all of these mechanisms are employed by tolerant plant types (Munns and Tester, 2008). Genes showing altered expression are primarily responsible for osmotic adjustment and osmolyte production. The second, ionic phase of salt stress occurs slightly later, with minimum overlap of changes in gene expression between genes associated with the ionic and osmotic phases of salt stress. There are a large number of genes identified as being associated with the ionic phase, many of which are involved in responses to toxic cellular concentrations of $\mathrm{Na}^{+}$ions (Shavrukov, 2013).

In present study, a few of the salt responsive genes were selected with the evidences of involving in both of these stress components of salinity stress. 
Accordingly, OsNHX1 OsTPS1, OsMAPK5 and $O s C D P K 7$ candidate genes were selected to study the differential expression of these genes in four local rice varieties viz., At354 (salinity tolerant improved variety), Godawee, Kuruwi Perunel (salinity tolerant traditional varieties), and Suwandel (salinity susceptible variety) at the whole plant level under salinity stress with the aim of understanding the expression dynamics under different genetic backgrounds exhibiting differential pattern of salinity tolerant mechanisms. In order to assess the candidate gene specific expression, gene specific RT-PCR primers were designed according to intron-spanning assay as the PCR products derived from the cDNA could be easily distinguished from the larger intron-containing products derived from contaminating genomic DNA. Resulted positive amplification in all of these designed primers with the expected size of PCR product derived from cDNA indicated the success of designing gene specific RT-PCR primers for the assessment of gene expression using semiquantitative PCR. Present results revealed the constitutive expression of OsTPI housekeeping gene in all four varieties irrespective of the different genetic background, developmental and environmental conditions indicating the successful synthesis of cDNA in all the samples harvested from four varieties at three different time intervals (before salinization, $24 \mathrm{~h}$ after salinization and $72 \mathrm{~h}$ after salinization).

According to previous studies it was reported that OsNHX1 OsTPS1, OsMAPK5 and $O s C D P K 7$ genes exhibit different functional involvement in mediating salinity tolerant mechanisms under salinity stress (Ahmadi et al.,2011; Gupta and Huang, 2014; Kumar et al.,2013; Ismail et al., 2007; Chen et al., 2007; Xiong and Yang, 2003; Saijo et al.,2000; Maksup et al., 2013).

OsNHX1 gene is one of the intracellular NHX proteins which are $\mathrm{Na}^{+}$, $\mathrm{K}^{+} / \mathrm{H}^{+}$antiporters involved in $\mathrm{K}+$ homeostasis, endosomal $\mathrm{pH}$ regulation, and salt tolerance (Kumar et al., 2013). In rice, 4 vacuolar $\mathrm{Na}^{+} / \mathrm{H}^{+}$antiporters (OsNHX1-4) and one endosomal $\mathrm{Na}^{+} / \mathrm{H}^{+}$antiporter (OsNHX5) have been reported (Bassil et al., 2012). Of them, Chen et al., (2007) reported that over-expression of $O s N H X 1$ in rice and in maize has improved salt tolerance by enhancing the compartmentalization of $\mathrm{Na}^{+}$into the vacuoles.

Calcium-dependent protein kinases (CDPKs) play important roles in regulating downstream components in calcium signalling pathways. (Asano et al., 2011). Calcium plays an important role as a messenger in various signal transduction pathways (Trewavas and Malho 1998; Sanders et al., 1999; Berridge et al., 2000; Sanders et al., 2002). It has been well established that high salt stress rapidly leads to cytosolic $\mathrm{Ca}^{2+}$ spiking. This event spontaneously initiates the stress signalling pathways for stress tolerance via stimulating various $\mathrm{Ca}^{2+}$ binding proteins including calcineurin B-like protein-CBLinteracting protein kinase (CBL-CIPKs), 
Calcium-dependent protein kinases (CDPKs) and calmodulins (Mahajan et al., 2008; Kader and Lindberg, 2010). In rice, the CDPKs constitute a large multigene family consisting of 29 genes, but the biological functions and functional divergence or redundancy of most of these genes remain unclear (Asano et al., 2011). With regard to that Saijo et al. (2000) reported transgenic rice plants overexpressing OsCDPK7 showed enhanced tolerance to cold, salt and drought stresses.

In addition, Mitogen activated protein kinase (MAPK) cascades too play a crucial role in salt stress signal transduction pathways in rice (Kumar et al., 2013). This phosphorylation cascade typically consists of three functionally interlinked protein kinases: a MAP kinase kinase kinase (MAPKKK), a MAP kinase kinase (MAPKK), and a MAP kinase (MAPK). In this phosphorylation module, a MAPKKK phosphorylates and activates a particular MAPKK, which in turn phosphorylates and activates a MAPK. Activated MAPK often is imported into the nucleus, where it phosphorylates and activates specific downstream signalling components such as transcription factors (Khokhlatchev et al., 1998). Several salt-inducible MAPKs have been reported in rice. Biotic and abiotic stress inducible OSMAPK5 has been cloned and over-expressed in rice which subsequently exhibited increased tolerance to salt, drought and cold stresses with increased kinase activity (Xiong and Yang, 2003).

The osmoprotectants (organic solutes) are one of the most important factors to protect plant cells from dehydration and salinity (Rontein et al., 2002; YamaguchiShinozaki et al., 2002). The organic solutes protect plants from abiotic stress by osmotic adjustment, detoxification of reactive oxygen species (ROS) and stabilization of the quaternary structure of proteins (Bohnert and Jensen, 1996). The most important plant osmoprotectants are proline, glycine betaine, trehalose and myoinositol (Kumar et al., 2013). In plants, the synthesis of this sugar occurs normally by the formation of the trehalose-6-phosphate (T6P) from the UDP-glucose and glucose6-phosphate, a reaction catalyzed by the trehalose 6-phosphate synthase (TPS). Li et al. (2011) have shown that over-expression of OsTPS1 gene encoding trehalose-6phosphate synthase in rice improved the tolerance of rice to high salinity and other abiotic stresses. Over-expression of this gene in rice is associated with increased level of trehalose and proline along with upregulation of some of the stress inducible genes including WSI18, RAB16C, HSP70 and ELIP (Turan et al., 2012).

In this experiment as the amplification was repeated two times it was able to confirm the reproducibility of the specific expression profiles resulted in each variety at different time intervals under salinity stress. Under non-saline condition relatively higher expression of these genes was detected in Godawee and Suwandel compared to At354 and Kuruwi Perunel. Out of four genes, expression of $O s N H X 1$, OsCDPK7 and OsMAPK5 genes were upregulated in At354, Kuruwi Perunel and 
Godawee at $24 \mathrm{~h}$ after salinity stress. This indicates the comparative functional activation of these 3 genes under salinity stress mediating the salt tolerant mechanisms in At354, Godawee and Kuruwi Perunel, salinity tolerant varieties. Chen et al. (2007), Saijo et al. (2000), Kawasaki et al. (2001) and Xiong and Yang (2003) have reported that over-expression of these three genes could enhance the salinity tolerance showing an agreement with the present results. With the extension of time under salinity stress up to $72 \mathrm{~h}$, continuous expression of these three genes was observed in Kuruwi Perunel and Godawee, whereas expression was comparatively down-regulated in At354 to the approximately same level under nonstress condition. With this observed differential expression behavior in At354 it could be speculated that At354 might be adapted to stress relatively early compared to Godawee and Kuruwi Perunel, where expression of genes are less pronounced with the adaptation of plant. Kawasaki et al. (2001), was also suggested that declining of amount of transcripts with the time after upregulation of a gene might be due to acquiring of early adaptation to stress in which abundance of transcript returned to the level under non- stress condition. On the other hand, Saijo et al. (2000), and Hirt, (1999) speculated that with respect to the regulation of expression in $O S C D P K 7$ and OsMAPK5 there could be another posttranslational mechanism(s) of regulating kinase activity of these genes in plant cell under salinity stress. One such mechanism is the degradation of activated OsCDPK7 and $O S M A P K 5$ proteins immediately after it has transduced signal(s) and transcriptional up-regulation of the gene is to compensate for the loss of the OsCDPK7 and OSMAPK5 protein due to turnover of the relevant protein under stress. Therefore, it could be suggested that down-regulation of expression of OsCDPK7 and OsMAPK5 genes in $A t 354$ at $72 \mathrm{~h}$ after salinity stress may be due to the comparatively less degradation rate of OsCDPK7 and OsMAPK5 proteins in At354.

In Suwandel, salinity susceptible variety, eventhough OsNHX1 and OsMAPK5 genes were expressed under non-saline condition, expression of these two genes were drastically down-regulated under salinity stress. This fact indicates the hindering of the expression of particular genes in Suwandel under salinity stress. However, expression of OsCDPK7 was relatively down-regulated 24 after salinity stress and again it was noted the upregulation of gene $72 \mathrm{~h}$ after salinity stress. Kawasaki et al. (2001) was also reported relative difference in the expression of OsCDPK7 with the time under salinity stress in contrasting rice genotypes of Pokkali (salinity tolerant) and IR29 (salinity susceptible). Accordingly, it was noted that up-regulation of expression in OsCDPK7 gene in Pokkali during initial periods of salt stress specially 1 hour after salt stress but was not regulated significantly in IR29. Further, Kawasaki et al. (2001) reported that at the $3 \mathrm{~h}$ and $6 \mathrm{~h}$ time points, $O s C D P K$ was up-regulated in both lines, suggesting a difference between the two lines in signal transduction at the early stages of stress and delay in the processing of signals could lead 
to the ineffective response of $I R 29$ to salt stress. According to these previous evidences, it could be suggested that Suwandel, salinity susceptible variety of this study, exhibited delayed expression of OsCDPK7 under salinity stress as in IR 29.

Similar to the expressional behaviour of OsNHX1, OsCDPK7 and OsMAPK5, OSTPS1 also exhibited comparative upregulation of expression in At354 and Godawee at $24 \mathrm{~h}$ after salinity stress indicating comparative functional activation of OSTPS1 gene under salinity stress. In contrast, progressive downregulation of gene expression throughout the studied time period under salinity stress, compared to non- stress condition in Suwandel, indicates the significant suppression of normal cellular functioning of OsTPS1 gene in Suwandel under salinity stress. At the time of $72 \mathrm{~h}$ after salinity stress transcript abundance of OSTPS1 gene in At354 and Godawee were comparable to their non-stress condition suggesting both tolerant varieties might have early adaptation response to salinity stress with respect to the OSTPS1 gene. In contrast to the regulation pattern of OSTPS1 gene in At354 and Godawee, OsTPS1 gene was upregulated in Kuruwi Perunel with a certain delay of time period i.e. $72 \mathrm{~h}$ after salinity stress. Due to delay in response with respect to OSTPS1 gene, it could be suggested that Kuruwi Perunel may have some other osmoprotectants other than trehalose conferring similar functional mechanism under salinity stress.

In the present study, according to an overall expression of four selected salt responsive genes in the four varieties at different time period at whole plant level, exhibited differential level of expression over the tested time period indicating their expression dynamics with respect to these genes under non-saline and salinity stress condition. However, it should be noted that it was difficult to draw more precise inferences regarding the relative expression of genes using semi-quantitative RT-PCR analysis. Therefore, it is required to conduct further experiments utilizing more advanced technologies such as microarray, RNAseq, quantitative RT-PCR to reveal differential expression of salinity responsive genes in different rice varieties conferring tolerance to salinity in varying limits.

\section{ACKNOWLEDGEMENT}

The Global Rice Science scholarship 2011, awarded by the International Rice Research Institute (IRRI) is greatly appreciated for providing financial support and research facilities.

\section{REFERENCES}

Ahmadi, N., Negrao, S., Katsantonis, D., Frouin, J., Ploux, J., Letourmy, P., Droc, G., Babo, P., Trindade, H., Bruschi, G., Greco, R. Oliveira, M. M., PiVanelli, P. and Courtois, B. (2011). Targeted association analysis identified japonica rice varieties achieving $\mathrm{Na}^{+} / \mathrm{K}^{+}$homeostasis without the allelic make-up of the salt tolerant indica variety Nona Bokra. Theoretical 
and Applied Genetics, 123: 881-895.

DOI: $10.1007 / \mathrm{s} 00122-011-1634-4$

Ashraf, M. and O'Leary, J.W. (1996). Responses of some newly developed salt tolerant genotype of spring wheat to salt stress: Yield components and ion distribution. Journal of Agronomy and Crop Science, $\quad$ 176: $\quad 91-101$. DOI:10.1111/j.1439037X.1996.tb004 51.x

Asano, T., Hakata, M., Nakamura, H., Aoki, N., Komatsu, S., Ichikawa, H., Hirochika, H. and Ohsugi, R. (2011). Functional characterisation of OsCPK21, a calcium dependent protein kinase that confers salt tolerance in rice. Plant Molecular Biology, 75: 179-191.

DOI: 10.1007/s11103-010-9717-1.

Basu, S. and Roychoudhury, A. (2014). Expression profiling of abiotic stressinducible genes in response to multiple stresses in rice (Oryza sativa L.) varieties with contrasting level of stress tolerance. BioMed Research International: 1-12. DOI: $10.1155 / 2014 / 706890$

Bassil, E., Coku, A. and Blumwald, E. (2012). Cellular ion homeostasis: emerging roles of intracellular NHX $\mathrm{Na}^{+} / \mathrm{H}^{+}$antiporters in plant growth and development. Journal of Experimental Botany, 63: 5727-5740.

DOI: $10.1093 / \mathrm{jxb} / \mathrm{ers} 250$

Berridge, M.J., Lipp, P. and Bootman, M.D. (2000). The versatility and universality of calcium signalling. Nature Reviews Molecular Cell Biology, 1: 11-21. DOI:10.1038/35036035
Bohnert, H.J. and Jensen, R.G. (1996). Strategies for engineering water-stress tolerance in plants. Trends in Biotechnology, 14: 89-97. DOI:10.1016/01677799(96)80929-2

Boonburapong, B. and Buaboocha, T. (2007). Genome-wide identification and analyses of the rice calmodulin and related potential calcium sensor proteins. BMC Plant Biology, 7(4): Available from: http://www.ncbi.nlm. nih.gov/pmc/articles/ PMC1797041/ DOI: 10.1186/1471-2229-7-4.

Chen, F., Li, Q., Sun, L. and He, Z. (2006). The rice 14-3-3 gene family and its involvement in responses to biotic and abiotic stress. DNA Research, 13: 5363.

DOI:10.1093/dnares/ds1001

Chen, M., Chen, Q.J., Niu, X.J., Zhang, R., Li, H.Q. and Xu, C.Y. (2007). Expression of $O s N H X 1$ gene in maize confers salt tolerance and promotes plant growth in the field. Plant, Soil and Environment, 53: 490-498.

Chinnusamy, V., Jagendorf, A. and Zhu, J.K. (2005). Understanding and improving salt tolerance in plants. Crop Science, 45: 437-448. DOI:10.2135/cropsci2005.0437

Fukuda, A., Nakamura, A., Hara, N., Toki, S. and Tanaka, Y. (2010). Molecular and functional analyses of rice NHXtype $\mathrm{Na}^{+} / \mathrm{H}^{+}$antiporter genes. Planta, 233(1): 175-188.

DOI:10.1007/s00425-010-1289-4

Garciadeblas, B., Senn, M.E., Banuelos, M.A. and Rodriguez-Navarro, A. (2003). Sodium transport and HKT transporters: the rice model. The Plant 
Journal, 34: 788-801.

DOI:10.1046/j.1365313X.2003.01764 . $\mathrm{X}$

Gregorio, G.B., Senadhira, D. and Mendoza, R.D. (1997). Screening rice for salinity tolerance. IRRI Discussion Paper Series No 22-International Rice Research Institute Los Banos Laguna Philippines, 13.

Gupta, B. and Huang, B. (2014). Mechanism of Salinity Tolerance in Plants: Physiological, Biochemical, and Molecular Characterization. International Journal of Genomics, Available from: https://www.hindawi.com/journals/ijg/ 2014/701596/.

DOI: $10.1155 / 2014 / 701596$

Hirt, H. (1999). Transcriptional upregulation of signalling pathways: more complex than anticipated? Trends in Plant Science, 4: 7-8.

DOI: $10.1016 / \mathrm{S} 13601385(98) 01359-4$

Horie, T., Costa, A., Kim, T.H., Han, M.J., Horie, R., Leung, H.Y., Miyao, A., Hirochika, H., An, G. and Schroeder, J.I. (2007). Rice OsHKT2; 1 transporter mediates large $\mathrm{Na}^{+}$influx component into $\mathrm{K}^{+}$starved roots for growth. The EMBO Journal, 26(12): 3003-3014. DOI:10.1038/sj.emboj.7601732

Ismail, A.M, Heuer, S., Thomson, M.J. and Wissuwa, M., (2007). Genetic and genomic approaches to develop rice germplasm for problem soils. Plant Molecular Biology, 65: 547-570. DOI:10.1007/s11103-007-9215-2

Kader, M.A. and Lindberg, S. (2010). Cytosolic calcium and $\mathrm{pH}$ signalling in plants under salinity stress. Plant
Signaling \& Behavior, 5: 233-238.

Kawasaki, S., Borchert, C., Deyholos, M., Wang, H., Brazille, S., Kawai, K., Galbraith, D. and Bohnert, H.J. (2001). Gene expression profiles during the initial phase of salt stress in rice. The Plant cell, 13: 889-905. DOI:10.1105/tpc.13.4.889

Khokhlatchev, A.V., Canagarajah, B., Wilsbacher, J., Robinson, M., Atkinson, M., Goldsmith, E., and Cobb, M.H. (1998). Phosphorylation of the MAP kinase ERK2 promotes its homodimerization and nuclear translocation. Cell, 93: 605-615. DOI: 10.1016/S00928674(00)81189-7

Khan, M., Takasaki, H. and Komatsu, S. (2005). Comprehensive phosphorproteome analysis in rice and identification of phosphoproteins responsive to different hormones/stresses. Journal of Proteome Research, 4: 1592-1599.

Kumar, K., Kumar, M., Kim, S., Ryu, H. and Cho, Y. (2013). Insights into genomics of salt stress response in rice. Rice, 6(27): 1-15. DOI:10.1186/19398433-6-27

Lafitte, H.R, Ismail, A.M and Bennett, J. (2004). Abiotic stress tolerance in rice for Asia: progress and the future. In: "New directions for a diverse planet", Proceedings of the $4^{\text {th }}$ International crop Science Congress, $26^{\text {th }}$ September to 1st October in 2004, Brisbane, Australia.

Liu, J.G., Zhang, Z., Qin, Q.L., Peng, R.H., Xiong, A.S., Chen, J.M., Xu, F., Zhu, H., Yao, Q.H. (2007). Isolated and characterization of a cDNA encoding 
ethylene-responsive element binding protein (EREBP)/ AP2-type protein, $\mathrm{RCBF} 2$, in Oryza sativa L. Biotechnology Letters, 29: 165-173. DOI:10.1007/s10529-006-9214-4

Li, H.W., Zang, B.S., Deng, X.W. and Wang, X.P. (2011). Overexpression of the trehalose-6-phosphate synthase gene OsTPS1 enhances abiotic stress tolerance in rice. Planta 234: 10071018. DOI:10.1007/s00425-011-14580

Mahajan, S., Pandey, G.K. and Tuteja, N. (2008). Calcium and salt-stress signalling in plants: shedding light on SOS pathway. Archives of Biochemistry and Biophysics, 471: 146-158.

DOI:10.1016/j.abb.2008.01.010

Maksup, S., Supaibulwatana, K. and Selvaraj, G. (2013). High-quality reference genes for quantifying the transcriptional responses of Oryza sativa L. (ssp. indica and japonica) to abiotic stress conditions. Chinese science bulletin, 58(16): 1919-1930. DOI:10.1007/s11434-013-5726-1

Martinez-Atienza, J., Jiang, X., Garciadeblas, B., Mendoza, I., Zhu, J.K., Pardo, J.M. and Quintero, F.J. (2007). Conservation of the salt overly sensitive pathway in rice. Plant Physiology, 143: 1001-1012. DOI:10.1104/pp.106.092635

Matsukura, S., Mizoi, J., Yoshida, T., Todaka, D., Ito, Y., Maruyama, K., Shinozaki, K. and YamaguchiShinozaki, K. (2010). Comprehensive analysis of rice DREB2-type genes that encode transcription factors involved in the expression of abiotic stressresponsive genes. Molecular Genetics and Genomics, 283: 185-196.

DOI: $10.1007 / \mathrm{s} 00438-009-0506-y$

Moradi, F., Ismail, A.M., Gregorio, G.B. and Egdane, J. A. (2003). Salinity tolerance of rice during reproductive development and association with tolerance at the seedling stage. Indian Journal of Plant Physiology, 8: 105116.

Moradi, F. and Ismail, A.M. (2007). Responses of photosynthesis, chlorophyll fluorescence and ROS scavenging system to salt stress during seedling and reproductive stages in rice. Annals of Botany, 99: 1161-1173.

DOI:10.1093/aob/mcm052

Munns, R. (2002). Comparative physiology of salt and water stress. Plant, Cell and Environment, 25: 239-250. DOI:10.1046/j.00168025.2001.00808. $\mathrm{X}$

Munns, R. (2005). Genes and salt tolerance: bringing them together. New Phytologist, 167: 645-663. DOI:10.1111/j.14698137.2005.01487. $\mathrm{X}$

Munns, R., James, R.A. and Lauchli, A. (2006). Approaches to increasing the salt tolerance of wheat and other cereals. Journal of Experimental Botany, 57: 1025-1043. DOI:10.1093/jxb/erj100

Munns, R, and Tester, M. (2008). Mechanisms of salinity tolerance. Annual Review of Plant Biology, 59: 651-681.

DOI:10.1146/annurev.arplant.59.0326 07.092911 
Negrão, S., Courtois, B., Ahmadi, N., Abreu, I., Saibo, N. and Oliveira, M.M. (2011). Recent updates on salinity stress in rice: from physiological to molecular responses. Critical Reviews in Plant Sciences, 30(4): 329-377.

DOI: $10.1080 / 07352689.2011 .5877$ 25

Pearson, G.A. and Bernstein, L. (1959). Salinity effects at several growth stages of rice. Agronomy Journal, 51: 654657.

Peng S. and Ismail, A.M. (2004). Physiological basis of yield and environmental adaptation in rice. In: Nguyen, H.T. and Blum, A., (Eds.), Physiology and biotechnology integration for plant breeding. Marcel Dekker, New York, 83-140.

Roshandel, P. and Flowers, T. (2009). The ionic effects of $\mathrm{NaCl}$ on physiology and gene expression in rice genotypes differing in salt tolerance. Plant and Soil, 315: 35-147.

DOI: 10.1007/s11104-008-9738-6

Rontein, D., Basset, G. and Hanson, A.D. (2002). Metabolic engineering of osmoprotectant accumulation in plants. Metabolic Engineering, 4, 49-56.

DOI: 10.1006/mben.2001.0208

Saijo, Y., Hata, S., Kyozuka, J., Shimamoto K. and Izui, K. (2000). Overexpression of a single $\mathrm{Ca}^{2+}$ dependent protein kinase confers both cold and salt/drought tolerance on rice plants. The Plant Journal, 23: 319-327.

Sambrook, J., Fritsch, F. and Maniatis, T. (1989). Molecular cloning: A laboratory manual, $2^{\text {nd }}$ edition. Cold Spring Harbor, NY, CSHL Press.
Sanders, D., Brownlee, C. and Harper, J.F. (1999). Communicating with calcium. Plant Cell, 11: 691-706. DOI:10.1105/tpc.11.4.691

Sanders, D., Pelloux, J., Brownlee, C. and Harper, J.F. (2002). Calcium at the crossroads of signalling. Plant Cell, 14: 401-417.

DOI:10.1105/tpc.00289

Schneider, C. A., Rasband, W. S. and Eliceiri, K. W. (2012). NIH Image to ImageJ: 25 years of image analysis, Nature Methods, 9(7): 671-675.

Shavrukov,Y. (2013). Salt stress or salt shock: which genes are we studying?. Journal of Experimental Botany, 64 (1): 119-127.

DOI: $10.1093 / \mathrm{jxb} / \mathrm{ers} 316$

Trewavas, A.J. and Malho, R. (1998). $\mathrm{Ca}^{2+}$ signalling in plant cells: the big network. Current Opinion in Plant Biology, 1: 428-433.

DOI:10.1016/S13695266(98)80268-9

Turan, S., Cornish, K. and Kumar, S. (2012). Salinity tolerance in plants: Breeding and genetic engineering. Australian journal of crop science, 6 (9): 1337-1348.

Wang, X.S., Zhu, H.B., Jin, G.L., Liu, H.L., Wu, W.R. and Zhu, J. (2007). Genome scale identification and analysis of LEA genes in rice (Oryza sativa L.). Plant Science, 172: 414-420. DOI:10.1016/j.plantsci.2006.10.004

Wu, Y., Wang, Q., Ma, Y. and Chua, C. (2005). Isolation and expression analysis of salt up-regulated ESTs in upland rice using PCR-based subtractive suppression hybridization method. Plant Science, 168: 847-853. 
DOI:10.1016/j.plantsci.2004.10.020

Xiong, L. and Yang, Y. (2003). Disease resistance and abiotic stress tolerance in rice are inversely modulated by an abscisic acid-inducible mitogenactivated protein kinase. Plant Cell, 15: 745-759. DOI:10.1105/tpc.008714

Yamaguchi-Shinozaki, K., Kasuga, M., Liu, Q., Nakashima, K., Sakuma, Y., Abe, H., Shinwari, Z.K., Seki, M. and Shinozaki, K. (2002). Biological mechanisms of drought stress response. JIRCAS Working Report, 23: $1-8$.

Yeo, A.R. and Flowers, T.J. (1986). Salinity resistance in rice (Oryza sativa L.) and a pyramiding approach to breeding varieties for saline soils. Australian Journal of Plant Physiology, 13: 16173. DOI: 10.1071/PP9860161

Yeo, A.R., Yeo, M.E., Flowers, S.A. and Flowers, T.J. (1990). Screening of rice (Oryza sativa L.) genotypes for physiological characters contributing to salinity resistance, and their relationship to overall performance. Theoretical and Applied Genetics, 79: 377-384.

DOI: $10.1007 / \mathrm{BF} 01186082$. 